\author{
Agnieszka Cejmer \\ Uniwersytet Mikołaja Kopernika w Toruniu \\ Instytut Języka Polskiego

\section{Analiza semantyczna percepcyjnego czasownika (s)kosztować}

Słowa klucze: semantyka strukturalna, czasowniki percepcyjne, analiza semantyczna, skosztować, kosztować

1. Przedmiotem badań w niniejszym artykule jest jednostka języka (termin przejęty z prac Andrzeja Bogusławskiego, por. Bogusławski 1976, 1988), w której skład wchodzi percepcyjny czasownik kosztować. Nie ma wattpliwości co do tego, że czasownik ten ma co najmniej dwa znaczenia, z czego jedno odnosi się do posiadania jakiejś ceny, wartości, a drugie jest związane z percepcją smakową; w tym wypadku obiektem zainteresowania będą wyłącznie te jednostki języka, które związane są z drugim znaczeniem. Ponadto z moich ustaleń wynika, że czasownik kosztować konstytuuje jedną jednostkę języka, odwołującą się do percepcji smakowej.

Analiza semantyczna wybranej jednostki przeprowadzona będzie w opozycji do bliskich znaczeniowo jednostek języka: ktoś smakuje coś oraz ktoś próbuje coś, ponieważ często podawane są one jako synonimiczne względem ktoś skosztował coś. Będę próbowała wykazać, że jednostka z czasownikiem kosztować nie tylko ma inne znaczenie, ale jest też bardziej złożona semantycznie od dwóch przytoczonych powyżej jednostek. 
Zanim przejdę do właściwej analizy semantycznej, przyjrzę się najpierw strukturze składniowej tej jednostki, szczególną uwagę poświęcając kwestii przypadka argumentu prawostronnego tej jednostki.

2. Zwyczajem polskiej leksykografii hasło słownikowe stanowi czasownik niedokonany. Powołując się na różne prace językoznawcze traktujące o aspekcie w języku polskim (por. Saloni 2010, Wartini 2009), przyjąć można, że tworzenie par aspektowych jest operacją gramatyczną. Istnieje możliwość derywowania zarówno form dokonanych od czasowników niedokonanych, jak i odwrotnie, co sprawia, że trudno jednoznacznie orzec, która forma jest bardziej podstawowa. W odniesieniu do czasownika percepcyjnego kosztować właściwsze wydaje się sięganie po jego formę dokonaną skosztować - ponieważ ta forma od razu przywodzi na myśl właśnie znaczenie percepcyjne. Ponadto zdania oparte na czasowniku niedokonanym nie tylko występują rzadko, ale zwykle, jak wskazują dane z Korpusu Języka Polskiego, są fragmentami wypowiedzi literackich, por.:

(1) Gtupi jest ten, kto na Cyprze nie kosztuje wina cypryjskiego, tylko piwo tyryjskie.

(2) O, Niemcy! Jeśli wam kiedy przebaczę, że blisko rok nie kosztowałem ludzkiego jedzenia...

(3) Matka cały dzień nie wychodziła z domu, mieszała ciagle truskawki i kosztowała je, czego jej zazdrościłem.

Forma skosztować odróżnia także czasownik percepcyjny od niepercepcyjnego, ponieważ ten drugi nie występuje w formie dokonanej ${ }^{2}$, por.:

1 Według Saloniego uznanie aspektu za kategorię gramatyczną jest tylko pewnym uproszczeniem, przybliżeniem tego zagadnienia. Jednak uważa on, że przy rozróżnianiu czasowników niedokonanych i dokonanych nie należy kierować się ich znaczeniem, a jedynie zasobem form, które im przysługują. W tym sensie parę czasowników kosztować - skosztować traktuję jako dwie alternatywne formy pojawiające się w różnych realizacjach tej samej jednostki języka.

2 Jednakże czasownik dokonany skosztować może być użyty także w innym znaczeniu, np. Jan skosztowat rozkoszy miłości, dlatego z pewnością nie można tej opozycji aspektowej kosztować - skosztować uznać za wystarczającą dla rozpoznania czasownika o znaczeniu percepcyjnym. 
(4) Kilogram bananów kosztowat 1,80 zt.

(5) *Kilogram bananów skosztowat 1,80 zt.

Kolejną ważną kwestią przy ustalaniu kształtu jednostki języka opartej na czasowniku skosztować jest określenie przypadka argumentu prawostronnego. Najczęściej uzupełnienie prawostronne przyjmuje formę dopełniacza, czego reprezentacją jest konstrukcja ktoś skosztowat czegoś. Jednak, na co wskazują liczne przykłady, nie zawsze tak jest. Por.:

(6) Bernardyn, siedzqc na szarym końcu, wprzódy już kosztowat młode wino, nazywane cienkuszem, stojace na stole, i jako amator z powołania, mocno się skrzywit.

(7) Przez ostatnie lata prawie też nie jadt, kazal sobie przynosić z ulubionych dawniej restauracji zapamiętane dania, ciasta, potrawy, kosztowat odrobine tylko po to, żeby przypomnieć sobie ich smak.

(8) To bardzo smaczna ryba. Jak zostanie podany, zadecyduja gospodynie. Jedno jest pewne - każdy powinien skosztować choć jedno dzwonko.

(9) Codziennie musiat czegoś skosztować na śniadanie, obiad i kolację. Jadt to, co byto powszechnie dostępne w sieciach restauracji.

(10) Tecumesh tylko raz skosztowat rumu i odtad już wiedział, iż służy on osłabieniu woli i ogłupianiu ludzi, postanowił zatem nigdy więcej nie wziqć do ust ani kropli tej trucizny.

Zdania (6)-(8), a także przytoczone wcześniej zdanie (3) charakteryzuje użyta konstrukcja ktoś skosztował coś, gdzie uzupełnienie prawostronne (w tym wypadku będące dopełnieniem bliższym) jest realizowane w postaci biernika. Tymczasem zdania (9) oraz (10), a także liczne inne zdania przykładowe pojawiające się w tym artykule, to konstrukcje z dopełniaczem.

Wydawać by się mogło, że alternacja biernik - dopełniacz w przypadku omawianej jednostki oparta jest na stosunku między biernikiem całościowym a dopełniaczem cząstkowym (więcej na ten temat: Grochowski, Karolak, Topolińska 1984, Żelazko 1975). Oznacza to, że o ile będziemy mieć do czynienia ze zdaniem, gdzie argument prawostronny występować będzie w dopełniaczu, będzie to tzw. dopełniacz cząstkowy. Tym samym, kiedy zastosowany jest argument $\mathrm{w}$ bierniku, domyślamy się, że nadawca ma na myśli przedmiot w całości (przykładowe zdanie: ktośskosztował budyń), a stosując 
argument w dopełniaczu, ma na myśli jakąś jego część (na przykład w zdaniu: ktoś skosztowat budyniu). Czy jednak rzeczywiście opozycja między biernikiem a dopełniaczem jest równoznaczna z opozycją całości do części?

Wymienność biernika i dopełniacza występuje również w przypadku jednostek języka ktoś próbuje cośn oraz ktoś smakuje coś. Odwołuję się do tych jednostek, ponieważ często są one traktowane jako synonimiczne wobec jednostki z czasownikiem kosztować, co oznacza, że niewątpliwie istnieją pewne podobieństwa między tymi jednostkami, a istnienie oboczności biernika i dopełniacza jest jednym z tych podobieństw. Sytuacja tutaj jest inna niż w przypadku oboczności przypadka argumentu prawostronnego jednostki z czasownikiem jeść. W tym wypadku wyraźnie argument dopełniaczowy informuje nas o tym, że do czynności użyta została tylko część wskazywanego obiektu, podczas gdy biernik informuje o całości, por.:

(11) Daniel zjadt (cała) zupę.

(12) Daniel zjadt (troche) zupy.

(13) Daniel skosztowat zupe.

(14) *Daniel skosztowat cała zupę.

(15) Daniel skosztowat zupy.

(16) Daniel skosztowat talerz zupy.

(17) *Daniel spróbowat cała zupę.

(18) Daniel spróbowat zupę.

(19) *Daniel posmakowat cata zupe.

(20) Daniel posmakowat zupę.

Zdania (11) i (12) pokazują, że uzupełnienie ich o informację na temat ilości użytego pokarmu, odpowiednio całości w przypadku argumentu biernikowego i części w przypadku argumentu dopełniaczowego, nie powoduje powstania zdań dewiacyjnych. Natomiast w wypadku jednostek z czasownikami próbować, smakować i kosztować informacja dotycząca całości powoduje sprzeczność, którą widać na przykładzie zdań (14), (17) i (19). Informacja na temat ilości może natomiast być zastosowana $\mathrm{w}$ zdaniach $\mathrm{z}$ argumentem dopełniaczowym - zdanie (16).

3 Mam na myśli jednostkę percepcyjną, nie zaś podobną do tej jednostkę ktoś próbuje czegoś, której realizacją jest zdanie np. ktoś próbuje swoich sił w biznesie. 
Gdyby jednak uważnie przyjrzeć się zdaniu (11), to mimo że argument można opisać wyrażeniem cały, nie oznacza to w istocie, że zupa została zjedzona w całości, w tym sensie, że zjedzono wszystko. Przyjąć należy, że również i w tym wypadku, mówiąc o całości, ma się na myśli jakąś część, która traktowana jest jako osobna całość. Charakter taki mają ,pewne części świata materialnego odzwierciedlające się w naszej percepcji językowej jako bezkształtne substancje i przez to podlegające identyfikacji wyłącznie jakościowej, nie referencyjnej [...]. Jako referenty wyrażeń argumentowych substancje te mogą występować tylko «porcjowane», tj. ujęte w kategoriach jakiejś mniej lub bardziej konwencjonalnej jednostki miary" (Topolińska w: Grochowski, Karolak, Topolińska 1984: 316). Topolińska mówi także o tym, że „wykładnikiem ilościowego nacechowania grupy imiennej, której referentem jest określona porcja danej substancji, może być też forma przypadkowa, por. Daj mi mleko, tj. np. 'to mleko, które stoi przed nami w dzbanku na stole' wobec Daj mi mleka - tzw. genitivus partitivus". Wówczas biernik w zdaniach (11)-(20) oznaczałby zupe, która np. stoi w talerzu na stole (jej porcja wyrażona jest poprzez wskazanie na konkretną jej ilość), podczas gdy dopełniacz oznaczałby bliżej nieokreśloną część zupy, nie odnosiłby się do konkretnej ilości, ale jedynie wyrażał cząstkowość, która jest immanentna nie z racji użytego predykatu, ale z racji cechy obiektu, który postrzegany jest jako bezkształtny. Czyniąc pewne uogólnienie, można powiedzieć, że pokarm jest pojmowany jako coś niepoliczalnego, bezkształtnego i porcjowalnego.

Jednakże fakt cząstkowości substancji pojawiających się jako wypełnienie argumentu prawostronnego nie wyjaśnia sprzeczności występującej w zdaniach (14), (17) i (19). Otóż charakter cząstkowy w tych zdaniach wykazują nie tylko same substancje (w przypadku których, jeśli mowa o całości, to raczej o „całej porcji” niż ,całej substancji”), ale wykazuje go też sam predykat. Opozycja biernika i dopełniacza, w chwili gdy w zdaniu nie pojawia się informacja precyzująca ilość użytego obiektu, nie czyni istotnych różnic semantycznych przy odczytaniu całych wypowiedzi, por.:

(21) Staś skosztowat kaszankę.

(22) Staś skosztowat kaszanki.

Według mojej hipotezy w obu zdaniach, (21) i (22), nadawca ma na myśli tylko część kaszanki, która została skosztowana. Przy czym dopuszczam ist- 
nienie subtelnej różnicy, która miałaby mówić o tym, że zdanie (21) informuje, że określenie ilości skosztowanej kaszanki nie jest możliwe, podczas gdy zdanie (22) tej możliwości nie wyklucza.

Zuzanna Topolińska zauważa specyficzny charakter dopełniacza, który według autorki - nie tworzy właściwej kategorii przypadka. Stwierdza ona, że ,na pozycje genetiwu wchodzą argumenty, które w poziomie zdania pozostają w stosunku akuzatywnym lub nominatywnym" (Topolińska 2010: 29). Również w wypadku badanych jednostek dopełniacz nie tworzy nowych jakości, ale wciąż pozostaje w stosunku kauzatywnym względem czasownika. Innymi słowy, argument jest obiektem operacji konstytuującej daną propozycję, działanie argumentu nominatywnego (ktoś) jest ukierunkowane na referenta akuzatywnego (coś), który pozostaje w stosunku biernym (por. Topolińska 2010). Forma dopełniacza wyraża cząstkowość, a powstanie tej formy może wynikać z pominięcia wyrażenia określającego ilość, które - jeśli występuje - przyjmuje postać biernika, por.:

(23) Zofia kosztuje nalewki.

(24) Zofia kosztuje kieliszek nalewki.

(25) Zofia kosztuje odrobine nalewki.

Pojawienie się biernika na pozycji argumentu prawostronnego może być wynikiem różnych operacji językowych związanych, na przykład, z wypieraniem dopełniacza przez biernik. W istocie wydaje się to w przypadku jednostek z czasownikami próbować, smakować i skosztować zabiegiem nie wpływającym na wartość semantyczną tych jednostek. Z tego względu uznałam, że nie należy tworzyć pary jednostek ktoś skosztowat coś i ktoś skosztował czegoś, wystarczy posługiwać się jednym ciągiem ktośs skosztował coś i przyjąć, że wariant dopełniaczowy jest efektem operacji na całej klasie jednostek czasownikowych.

Wymienność dopełniacza i biernika występuje często w języku polskim, wyraźnie ujawnia się podczas negacji, por.:

(26) Daniel je mięso.

(27) Daniel nie je mięsa.

(28) Kasia próbuje zupę.

(29) Kasia nie próbuje zupy. 
W zdaniach (26) i (27) oraz (28) i (29) nie zmienia się stosunek argumentu do predykatu, argument pozostaje w każdym z tych zdań w stosunku akuzatywnym wobec predykatu, mimo że przyjmuje on raz formę biernika, a raz formę dopełniacza. Przykład ten służy stwierdzeniu faktu, iż ta konkretnie para biernik - dopełniacz w języku polskim często występuje wymiennie wobec predykatu. Jednak wymiana ta nie tworzy nowej jakości semantycznej. Wszystko to pozwala mi na ustalenie podstawowej postaci jednostki ktoś kosztuje coś, gdzie argument prawostronny wyrażony jest w bierniku, co lepiej charakteryzuje akuzatywny stosunek argumentu do predykatu.

3. Analizując znaczenie jednostki ktoś kosztuje coś, odniosę się do kilku prac leksykograficznych. Wszystkie przejrzane przeze mnie słowniki definiują tę jednostkę w relacji do percepcji smakowej. Jednocześnie jako podstawowy element semantyczny podają one zwykle czynność jedzenia lub picia. Por::

ISJP: Jeśli ktoś kosztuje jedzenia lub napojów, to sprawdza, jak smakuja.

SJPDor: Jeść lub pić coś w celu zbadania smaku, próbować smakiem.

SJPSz: Jeść lub pić coś w celu zbadania smaku; próbować.

SWJP: Badać smak potraw, napojów jedzac lub pijac niewielka ich ilość; próbować.

Uwagę zwraca definicja podana w SWJP, w której pojawia się określenie „niewielka ilość”. Faktem jest, że w wypowiedziach zawierających jednostkę ktoś kosztuje coś często pojawia się informacja dotycząca ilości i to zwykle ilości względnie małych, por::

(30) Jacek skosztował odrobinę ravioli.

(31) Halina z przyjemnościq skosztowała nieco budyniu.

(32) Marcin skosztowat trochę sałatki.

(33) Niewatpliwie największym zainteresowaniem cieszyło sięjednak stoisko z miodami pitnymi. Można było skosztować odrobinkę, a następnie nabyć butelczynę na chtodne wieczory.

(34) 'Daniel skosztowat kawat tortu.

(35) ?Jacek skosztowat sporo budyniu. 
Jak już wcześniej wspominałam, omawiana jednostka niesie informację o partytywności obiektu. Niezależnie od tego, czy jest to konstrukcja z rekcją biernikową czy dopełniaczową, każdorazowo oznacza ona czynność, do której użyta została tylko część obiektu, a nie cały obiekt wskazany przez argument prawostronny. Jednak o tym, czy cząstkowość oznacza w tym wypadku mało czy dużo, nie można przesądzać. W świetle definicji proponowanej przez SWJP, mówiącej o niewielkiej ilości potrawy, zdania (30)-(33) uznać by należało za pleonastyczne. Idąc dalej tym tropem, skoro informacja dotycząca ilości spożytego pokarmu (konkretnie niewielkiej ilości) jest zawarta w samej treści jednostki ktoś skosztowat coś, zdania (34) i (35) powinny być zdaniami dewiacyjnymi, ponieważ zachodzi sprzeczność między niewielkq ilościq a sporq ilościq. Faktem jest, że o kosztowaniu dużej ilości czegoś słyszy się rzadko, jednak, jak będę próbowała w dalszej części udowodnić, wynika to z zupełnie innej własności semantycznej tej jednostki języka. Tymczasem zdania (34) i (35) zaznaczyłam jako wątpliwe, chociaż w moim mniemaniu dopuszczalne.

Natomiast zdania (30)-(33) nie budzą moich zastrzeżeń, ponieważ jednak pleonazm w języku potocznym występuje bardzo często, trudno tylko na tej podstawie polemizować z definicją w SWJP. Pojawienie się tego typu definicji, uwzględniającej ilość kosztowanego pokarmu, bierze się z pewnych spostrzeżeń, które potwierdzają również i moje obserwacje, mówiące o tym, że jednostka ta implikuje informację o użyciu tylko części obiektu. Nie należy jednak przesądzać o konkretnej ilości, której dookreślenie jest przecież możliwe w zdaniu. Ponadto wyrażenie „niewielka ilość”, jest nieścisłe, ponieważ to, czy talerz zupy uznamy za małą czy dużą jej ilość, jest bardzo względne. Wiemy natomiast, że talerz zupy nie jest całq zupq, ale jedynie jakąś jej częścią.

Przytoczone powyżej definicje słownikowe wskazują także na semantyczny związek badanej jednostki z samym aktem spożywania czegoś. Czasowniki jeść i pić nie pojawiają się tylko w definicji proponowanej przez ISJP.

Fakt jedzenia lub picia nie musi być związany z treścią badanej jednostki języka, może jedynie wynikać z wiedzy o świecie użytkownika języka. Jednak żeby ustalić, jaki jest związek semantyczny jednostki ktoś skosztowat coś z jednostkami ktoś zjadt coś oraz ktoś wypił coś, przeprowadzę test porównujący omawianą jednostkę z bliskoznacznymi ktoś próbuje coś oraz ktoś smakuje coś. 
(36) Po raz pierwszy spróbowałam waniliowego papierosa.

(37) Po raz pierwszy posmakowatam waniliowego papierosa.

(38) *Po raz pierwszy skosztowałam waniliowego papierosa.

(39) Posmakuj koniecznie te pomadke, jest truskawkowa!

(40) *Skosztuj koniecznie tę pomadkę/tej pomadki, jest truskawkowa!

(41) *Bartek polizat loda, ale go nie posmakowat.

(42) *Bartek polizat loda, ale go nie spróbowat.

(43) Bartek polizat loda, ale go nie skosztowat.

(44) 'Bartek spróbowat loda, ale go nie skosztowat.

(45) Bartek posmakowat loda, ale go nie skosztowat.

(46) Z tytu za całym orszakiem właściciel zajazdów i karczm przydrożnych Mierzykat szedt, pospólstwo gadało, że to on strawe gotowat i na znak, że nieotruta sam każdej skosztować będzie musiat, a dopiero później dostojeństwo do stołu zasiqdzie.

(47) Na co oni jeszcze gorliwiej zapewnili, że głodni nie sq, obiad przecież jedli przed wyjściem. Na te słowa gospodyni zaczęła nalegać, że koniecznie muszq czegoś skosztować.

(48) Bartek spróbowat pysznego tortu, ale nie zjadt nawet kawateczka tego tortu.

(49) Bartek posmakowat pysznego tortu, ale nie zjadt nawet kawałeczka tego tortu.

(50) *Bartek skosztowat pysznego tortu, ale nie zjadt nawet kawałeczka tego tortu.

Jednostki języka ktoś próbuje coś i ktoś smakuje coś semantycznie związane są z wyrażaniem doznawanych wrażeń percepcyjnych, których receptory znajdują się na języku. Kiedy mowa o smaku, to znaczy, że mowa o czymś, co czuć może tylko język. Jednakże zdania (36), (37) i (39) wskazują na fakt, iż percepcyjne jednostki języka związane z czasownikami próbować i smakować nie muszą dotyczyć jedzenia czy picia. W istocie koncentrują się one wokół tego, co ma smak, a nie zawsze jest to akurat pożywienie. Smak może być także właściwością innych rzeczy, które z jakichś przyczyn mają lub mogą mieć kontakt z językiem. To właśnie ów kontakt z narządem zmysłu (w tym wypadku z językiem) jest kluczowy dla jednostek ktoś smakuje coś i ktoś próbuje coś. Pomysł definiowania jednostek percepcyjnych poprzez odwołanie się do narządu zmysłu pojawia się w starszych pracach Wierzbickiej 
(por. Wierzbicka 1980), a także wykorzystany został z powodzeniem przez Dobaczewskiego w opisie jednostek percepcji wzrokowej (por. Dobaczewski 2002), a w odniesieniu do percepcji słuchowej w pracach Żurowskiego (por. Żurowski 2007). W przypadku jednostki ktoś skosztowat coś odwołanie się do narządu zmysłu nie byłoby wystarczające. Zdanie (43) dowodzi tego, że sam odbiór bodźca smakowego (który z pewnością ma miejsce w chwili kontaktu języka z żywnością, np. w sytuacji polizania), nie przesądza wcale o tym, że nastąpiło skosztowanie żywności. Oznacza to, że kosztowanie dotyczy czynności bardziej złożonej niż smakowanie czy próbowanie, której obok percepcji smakowej towarzyszy proces mentalny.

Zdania (38) i (40) są zdaniami dewiacyjnymi, co wskazuje na fakt, że w jednostce języka ktoś kosztuje coś tkwi informacja, w moim przekonaniu dotycząca właśnie jedzenia i picia, która uniemożliwia zastąpienie tą jednostką innych jednostek percepcji smakowej. Dlaczego nie można skosztować pomadki, a można jej posmakować? Właśnie w sytuacji kosztowania zawarta jest informacja o obiekcie czynności - taka informacja, że musi być on jadalny.

W tym miejscu pojawia się kolejne pytanie: czy obiekt musi być jadalny, skoro skosztowanie zakłada właśnie spożycie czegoś, czy też badana jednostka w jakiś inny sposób definiuje klasę obiektów jako obiekty jadalne? W zdaniach (44)-(45) wyraźnie zaznacza się różnica między jednostkami ktoś próbuje coś, ktoś smakuje coś i ktoś skosztowat coś. Zdania te potwierdzają tezę, że smakowanie i próbowanie nie jest tym samym, co kosztowanie. Elementem różniącym te jednostki jest brak koniecznego związku z jedzeniem, w wypadku próbowania i smakowania, podczas gdy związek ten zachodzi koniecznie w wypadku jednostki ktoś skosztowat coś. Potwierdzeniem tej tezy są również zdania (48)-(50), które pokazują, że jedzenie nie zawsze towarzyszy dwu pierwszym czynnościom, za to nie może nie towarzyszyć kosztowaniu. Z kolei zdania (46) i (47) podpowiadają, że nadawcy chodzi nawet bardziej o fakt właśnie zjedzenia, niż tylko poczucia smaku.

Wracając do wspomnianego ograniczenia klasy obiektów do obiektów jadalnych, można przyjać, że wynika ona z semantycznego związku kosztować z jeść. Oczywiście, takie ograniczenie ma miejsce tylko w mówieniu „serio”, co oznacza, że zarówno obiektem jedzenia, jak i smakowania może być coś niejadalnego. Czyni to jednak tego typu wypowiedzi wypowiedziami metaforycznymi lub mającymi jakiś szczególny charakter, por.: 
(51) Rewolucja zjada własne dzieci.

Mówiąc o tym, że pole semantyczne jednostki ktoś kosztuje coś zawiera niejako informację o obiekcie czynności, zauważyłam, że liczne zdania w Korpusie Języka Polskiego wskazują na to, że obiekty te nie tylko są jadalne, ale także uchodzą za smaczne, z założenia mają jakieś szczególne walory smakowe, por.:

(52) W naszych wspólnych podróżach i mnie zdarzało się skosztować cudowności z jego stotu.

(53) Co uważa pan za przysmak kuchni meksykańskiej, co koniecznie powinno się skosztować i co opatrzyłby pan klauzula ,tylko dla odważnych”?

(54) Ponadto osoby, które w tym dniu odwiedzity szkołe, miały okazje skosztować tradycyjnych polskich potraw, w tym m.in. kwaśnicy, barszczu, bigosu, a także oscypków i ogórków kiszonych.

(55) Do Mniewa przyjechaty setki ludzi, by odetchnać, postuchać ciętych przyśpiewek, pośmiać się i skosztować pysznej grochówki.

(56) Odbywaja się tam co roku targi - Gallusmarkt, na których można skosztować wyśmienitego piwa.

(57) Gdy ziemniaki byty już upieczone, państwo Piórkowie wyciagali je z popiołu i każdy mógł skosztować tego niezwykłego rarytasu.

(58) Wnaszym sklepie też można będzie tego dnia skosztować szwedzkich przysmaków, będzie także wiele innych atrakcji - twierdzi Marek Matuszczak z Ikea Katowice.

(59) Podczas kiermaszu można było również skosztować wielkanocnych specjatów.

(60) Na jarmarku [...] można również skosztować ekologicznych smakotyków prosto ze starego pieca.

Obiektem kosztowania są często rarytasy, specjały, smakołyki itp. Zupełnie jakby intencją jedzenia tych rzeczy było delektowanie się ich smakiem. Nie tylko spróbowanie czy posmakowanie, ale raczej uraczenie się smakiem, koncentrowanie się na smaku, jedzenie po to, żeby czuć smak. W tym sensie jest to coś innego niż spróbowanie czy posmakowanie, bo te czynności zdają się dotyczyć sytuacji, w której smak nie jest osobie znany. Kiedy mówimy o posmakowaniu czy spróbowaniu, mówimy też o jakimś doświadcze- 
niu percepcyjnym, które dostarczy nam pewnej nowej wiedzy. Celem tych dwóch czynności jest sprawdzenie smaku, poznanie smaku czy też ocenianie smaku. Tymczasem w zdaniach (52)-(60) widać wyraźnie, że podmiot wie, czego się spodziewać i właśnie dlatego, ze względu na spodziewane wrażenia smakowe, decyduje się coś zjeść lub wypić.

Nie oznacza to jednak, że definicja jednostki powinna wskazywać na to, że obiekt czynności to coś smacznego. Wydaje się, że koncentrowanie się na przyjemnym smaku przychodzi ludziom łatwiej, jednak nie oznacza to, że nie można kosztować czegoś całkiem zwykłego, por.:

(61) Podróżując miałem okazję kosztować przeróżnych postaci tego, co jest na całym świecie zwane „chlebem powszednim”, czyli kombinacji maki, wody, soli $[\ldots]$.

Można powiedzieć, że to, co nazwałam koncentrowaniem się na doznaniach smakowych, jest pewną, dosyć wyrafinowaną operacją umysłową. Za potwierdzenie takiej hipotezy mogą posłużyć przykłady odwołujące się do zwierząt czy niemowląt, które uznajemy za niezdolne do skomplikowanych procesów myślowych, por.:

(62) *Kot skosztowat kawatek ryby.

(63) Kot spróbowat kawatek ryby.

(64) ?Kot posmakowat kawatek ryby.

(65) *Niemowlę skosztowało kaszki.

(66) ?Niemowle posmakowato kaszkę.

(67) Niemowle spróbowało kaszki.

Zdania (62)-(67) wskazują na specyfikę czynności kosztowania, która w porównaniu do próbowania wymaga większych zdolności intelektualnych. Kwestia smakowania pozostaje w tym miejscu nierozstrzygnięta, należałoby przeprowadzić szerszą analizę tej jednostki, by stwierdzić, czy podmiotem tej czynności może być zwierzę lub niemowlę. Oczywiście w bajce, gdzie ma miejsce personifikacja postaci zwierzęcych, zdania (62) i (64) mogłyby z powodzeniem zostać użyte, jednak będzie to wówczas tłumaczone szczególnym kontekstem, właściwym wypowiedziom literackim. 
Przykłady (62)-(67) uzasadniają dobór wyrażenia ktoś w momencie ustalania walencji jednostki. Podmiot określony jest jako osoba, przez co odrzuca się z tej pozycji wszelkie byty niezdolne do pewnych procesów myślowych, które są treścią jednostki ktoś skosztowat coś.

Uznanie procesu myślowo-percepcyjnego (nie chodzi wyłącznie o odbieranie bodźca, ale także o analizowanie go) za podstawowy składnik semantyczny badanej jednostki, wyjaśnia także często pojawiającą się informację na temat ilości kosztowanej strawy. Otóż uznać można, że o tym, jak niewielka to była ilość, tylko domyślamy się na podstawie naszej wiedzy o świecie, która podpowiada nam, iż trudno o koncentrowanie się przez długi czas na odbieranych bodźcach smakowych. Łatwo jest przez chwilę skupić uwagę na smaku, ale dużo trudniej bez przerwy koncentrować się na nim podczas jedzenia całego garnka zupy. Wyjaśnia to również, dlaczego mówimy, że ktoś coś skosztowat, zamiast powiedzieć, że ktoś coś spróbowat. Na spróbowanie wystarczy najmniejszy kawałek, podczas gdy kosztowanie wymaga zjedzenia chociaż trochę, żeby też w trakcie mieć czas do namysłu nad tym, co się czuje.

4. Zgromadzony przeze mnie materiał dotyczący jednostki ktoś skosztowat coś pozwolił mi na postawienie następujących hipotez dotyczących tej jednostki:

- podstawowe znaczenie dotyczy czucia smaku i myślenia o tym smaku, co pozwala zaliczyć tę jednostkę języka do jednostek percepcyjnych (bardziej precyzyjne byłoby określenie mentalno-percepcyjne);

- zakres semantyczny tej jednostki obejmuje jedzenie i picie (w tym sensie, że oznacza ona, że się coś zjadło lub wypiło);

- nie jest to jednostka synonimiczna z ktoś smakuje coś ani z ktoś próbuje coś;

- w zakres semantyczny tej jednostki nie wchodzi informacja o konkretnej ilości pokarmu, ale wchodzi weń informacja o cząstkowości obiektu czynności.

Na podstawie powyższych ustaleń, zgodnie z regułami budowania definicji semantycznych (por. Bogusławski 1988, Grochowski 1993) oraz odwołując się do wyrażeń prostszych semantycznie, proponuję następującą definicję jednostki ktoś skosztowat coś: 


\section{Ktoś skosztowat cośs}

\section{Ktoś zjadt lub wypit jakq̨ś część czegoś, myśląc o tym, co czuje językiem, kiedy to robi}

W proponowanej definicji pojawia się sformułowanie czuć coś językiem, które odnosi się do definiowania percepcji poprzez odwołanie do narządu zmysłu. Faktem jest, że językiem można czuć nie tylko smak, ale również dotyk oraz zimno i ciepło, ale w tym wypadku takie szerokie rozumienie $c z u$ cia językiem (wykraczające poza zmysł smaku) jest nawet pożądane. Można przypuszczać, że proces myślowy, zachodzący w czasie kosztowania czegoś, dotyczy nie tylko czucia smaku, ale może również, zapewne w niewielkim stopniu, być poświęcony ocenie konsystencji czy temperatury potrawy. Są to kwestie dosyć skomplikowane, trudno rozstrzygnąć, czy temperatura i konsystencja są częścią smaku, a najbardziej oczywistym składnikiem smaku, nie ujętym w mojej definicji, wydaje się aromat. Język służy tutaj jako narząd rozpoznawczy, mówiący o tym, z jakim zmysłem mamy do czynienia. Nie jest moim celem odniesienie się do tego, co w sensie biologicznym odpowiada zmysłowi smaku, ale do tego, co jest powszechnie ze zmysłem smaku utożsamiane. Język wydaje się wystarczająco sugestywny.

Jednocześnie niezbędna jest informacja o tym, że to właśnie wrażenia smakowe są obiektem myśli w trakcie kosztowania. Gdyby z definicji wyeliminować narząd zmysłu, wówczas czucie odnosić by się mogło choćby do bólu żołądka lub uczucia sytości, które przecież mogą towarzyszyć jedzeniu. Czasownik czuć może wyrażać tak różne wrażenia zmysłowe (jest on czasownikiem stanowym obsługującym aż trzy zmysły w języku polskim: smak, zapach i dotyk), że konieczne jest uściślenie rodzaju percepcji, na którym podmiot się koncentruje.

Fraza ktoś myśli o tym, co czuje ma wyrażać proces mentalny, którego obiektem jest wrażenie zmysłowe, w tym wypadku wrażenie smakowe. Jednocześnie skomponowana przeze mnie definicja hierarchizuje wszystkie wyróżnione przeze mnie komponenty semantyczne badanej jednostki. Na pierwszym miejscu pojawia się komponent niezbędny, umożliwiający skosztowanie, czyli zjedzenie lub wypicie (możliwe byłoby ograniczenie dwóch czasowników do jednego: spożywać, ale postanowiłam oprzeć swoją definicję na tych dwóch, prostszych semantycznie elementach). Starałam się poka- 
zać, że jedzenie i picie jest tłem dla procesu percepcyjno-mentalnego, który jednak, bez tej czynności, nie mógłby się odbyć. Predykaty jeść i pić pojawiają się, analogicznie do opisywanego predykatu skosztować, w czasie przeszłym w aspekcie dokonanym. Uznałam, że skoro proponowany kształt jednostki zawiera czasownik w takiej formie, forma ta musi być zachowana w definicji. Forma niedokonana czasownika w czasie przeszłym myślat odpowiednia byłaby dla kształtu ktoś kosztowat coś.

Wyrażenie jakaś część nie jest w pełni zadowalające, jednak nie znalazłam lepszego na wyrażenie tej właściwości semantycznej badanej jednostki, która mówi o tym, że do realizacji czynności, która jest treścią jednostki, użyty zostanie tylko jakiś fragment obiektu reprezentowanego przez prawostronny argument przedmiotowy. Chcę tym samym podkreślić, że informacja o cząstkowości nie wynika z ograniczeń selekcyjnych argumentu prawostronnego, ponieważ argument ten może być referentem przedmiotu, który jest całością, ale predykat zakłada, że użyta zostanie tylko część tej całości. W zdaniach zawierających argument biernikowy nie dlatego odczytujemy informacje o częściowym użyciu obiektu, że prezentowany jest on przez argument przedmiotowy oznaczający cząstkowość, ale dlatego, że treść taką niesie sam predykat.

Test negacji badanej jednostki i jej definicji również daje zadowalające rezultaty, por.:

Nieprawda, ̇̇e ktoś skosztowat coś $s_{x}=$ Nieprawda, że ktoś zjadt lub wypit jakąś część czegoś, myśląc o tym, co czuje językiem, kiedy to robi

Z testu wynika, że skoro nie doszło do skosztowania, nie mogło też dojść do opisywanego procesu mentalno-percepcyjnego. $Z$ negacji definicji jednak nie wynika, że nie doszło do zjedzenia lub wypicia czegoś, co przecież może mieć miejsce niezależnie od skosztowania.

$\mathrm{Na}$ koniec wykorzystam proponowaną definicję, podstawiając ją w miejsce badanej jednostki w zdaniach, które w najbardziej wyraźny sposób pokazywały pewne semantyczne właściwości kosztowania, por.:

(68) Jacek zjadt odrobinę ravioli, myślac o tym, co czuje językiem, kiedy to robi. 
(69) *Po raz pierwszy zjadłam jakąś część waniliowego papierosa, myśląc o tym, co czuje językiem, kiedy to robię.

(70) Bartek polizał loda, ale nie zjadt jakiejś jego części, myślac o tym, co czuje językiem, kiedy to robi.

(71) *Bartek zjadt [jakaś część] pysznego tortu, myślqc o tym, co czuje językiem, kiedy to robi, ale nie zjadt nawet kawateczka tego tortu.

(72) *Kot zjadt kawatek ryby, myślac o tym, co czuje językiem, kiedy to robi.

Zdania, które były dewiacyjne, gdy zawierały jednostkę ktoś skosztowat $c o s ́$, pozostały dewiacyjne w chwili, kiedy jednostka ta została zastąpiona jej eksplikacją. Oznacza to, że definicja zawiera niezbędne komponenty semantyczne, których ujawnieniu służyły te zdania. Zdania (68) i (70) w sposób pozytywny pokazują, jakie są konieczne komponenty semantyczne, które znajdować się muszą w eksplikacji jednostki. Z kolei przykłady (69) i (71) pokazują sprzeczność wynikająca z semantycznego związku z jedzeniem lub piciem, a przykład (72) obrazuje proces mentalny, o który kot nie jest posądzany, co wywołuje sprzeczność zdań z użyciem zwierzęcia jako podmiotu czynności.

Podsumowując swoje dociekania na temat jednostki ktoś skosztowat coś, chciałabym zauważyć, że opis jednostek percepcyjnych jest skomplikowany ze względu na naturę samej percepcji. Do pewnego stopnia są to procesy uświadomione, do pewnego stopnia zachodzące niezależnie od woli człowieka. Omawiana jednostka przybliżyła mnie do tematu percepcji również w tym punkcie, że pokazała tę zależność między percepcją a procesami mentalnymi. W moim przekonaniu jednostek stricte percepcyjnych jest mniej, niż można by się tego spodziewać. W przypadku zmysłu smaku, obok jednostek podstawowych fundowanych na czasownikach smakować i próbować, istnieje co najmniej kilka innych jednostek, które wyrażają bardziej złożony proces, powiązany z percepcją, ale nie ograniczający się do niej (będzie to np. jednostka ktoś degustuje coś). W tym artykule przyjęte zostało nazywanie takich jednostek jednostkami mentalno-percepcyjnymi, co odzwierciedla ich złożony charakter. Klasyfikacja taka opiera się na założeniu, że proces mentalny i proces percepcyjny nie są tożsame, co w świetle doniesień biologów może budzić sprzeciw, wszak zarówno percepcja, jak i myślenie dzieją się 
w mózgu. Jednak dane językowe dowodzą, że z punktu widzenia semantyki języka są to odrębne procesy, mogące zachodzić niezależnie.

\section{Bibliografia}

Bogustawski A., 1976, O zasadach rejestracji jednostek języka, Poradnik Językowy 8, s. 356-364.

Boguszawski A., 1988, Język w stowniku. Desiderata semantyczne do wielkiego słownika polszczyzny, Wrocław: Zakład Narodowy im. Ossolińskich.

Dobaczewsкi A., 2002, Zjawiska percepcji wzrokowej. Studium semantyczne, Warszawa: KLF UW.

Grochowski M., 1993, Konwencje semantyczne a definiowanie wyrażeń językowych, Warszawa: Zakład Semiotyki Logicznej UW.

Grochowski M., Karolak S., TopolińsKa Z., 1984, Gramatyka wspótczesnego języka polskiego. Sktadnia, t. 1, Warszawa: PWN.

ISJP: BАŃко M. (red.), 2000, Inny stownik języka polskiego, t. 1, Warszawa: Wydawnictwo Naukowe PWN.

SALoni Z., 2010, Czasownik polski, Warszawa: Wiedza Powszechna.

SJPDor: DoRoszewski W. (red.), 1958-1969, Stownik języka polskiego, t. 4, Warszawa: Państwowe Wydawnictwo „Wiedza Powszechna”, PWN.

SJPSz: SzymczaK M. (red.), 1992, Stownik języka polskiego, t. 1, Warszawa: PWN.

SWJP: Dunaj B. (red.), 1999, Stownik wspótczesnego języka polskiego, t. 1, Warszawa: Wilga.

Topolińska Z., 2010, W sprawie przypadka: gawęda językoznawcza, Poznań: Wydawnictwo Naukowe UAM.

WARTINI M., 2009, Aspekt z określnikami krotności ograniczonej w języku rosyjskim i polskim (na materiale form czasu przeszłego), praca doktorska, http://www.sbc. org.pl/Content/19423/doktorat3005.pdf [10.12.2011].

Wierzbicka A., 1980, Lingua Mentalis. The Semantics of Natural Language, Sydney: Academic Press.

Żelazko K., 1975, Czasowniki przechodnie o sktadni wielorakiej w języku polskim, Wrocław: Zakład Narodowy im. Ossolińskich.

Żurowski S., 2007, Cechy semantyczne jednostki leksykalnej ktoś styszy coś, Prace Filologiczne 52, s. 469-480. 
The Polish perceptive verb (s)kosztować: A semantic study

( s u m m a r y)

The present article is devoted to a semantic study of the Polish perceptive verb kosztowac' 'to taste; to try'. First, it describes the shape of the unit of language formed by the verb kosztować - ktoś skosztowat coś, and its valency properties. Then, a detailed analysis of the unit ktoś skosztowat coś in opposition to two other units of taste perception - ktoś próbuje coś and ktoś smakuje coś is conducted. The article concludes with a proposal for a semantic explication of the examined unit. 